\title{
COMMENTS
}

\section{APPLICATION OF THE GOOD-FAITH-DOUBT TEST TO THE PRESUMPTION OF CONTINUED MAJORITY STATUS OF INCUMBENT UNIONS}

The National Labor Relations Act ${ }^{1}$ embodies two often-conflicting policy objectives: the promotion of industrial stability ${ }^{2}$ and the maximization of employee free choice. ${ }^{3}$ Underlying the Act is the assumption that industrial stability is best achieved by maintaining continuity in collective bargaining relationships. The policy objective of employee free choice is governed by the principle of inajority rule. ${ }^{4} \mathrm{Em}-$ ployees decide whetler to engage in collective bargaining with their employer, and, if they decide to bargain collectively, they choose a bargaining representative. Such basic decisions are the essence of einployee free choice. ${ }^{5}$

The National Labor Relations Board is primarily responsible for

1. 29 U.S.C. $\$ \$ 151-169$ (1976 \& Supp. III 1979).

2. Section 1 sets forth this basic policy of the Act:

Experience lias proved that protection by law of the right of employees to organize and bargain collectively safeguards commerce from injury, impairment, or imterruption, and promotes the flow of commerce by removing certain recognized sources of industrial strife and unrest, by encouraging practices fundamental to the frieudly adjustment of industrial disputes arising out of differences as to wages, lours, or other working conditions, and by restoring equality of bargaining power between employers and employees. Id. $\S 151$.

3. Section 7 of the Act provides:

Employees shall lave the right to self-organization, to form, jom, or assist labor organizations, to bargain collectively through representatives of their own choosing, and to engage in other concerted activities for the purpose of collective bargaining or other mutual aid or protection, and shall also have the right to refrain from any or all of such activities....

Id. § 157.

4. Section 9(a) of the Act, 29 U.S.C. $\$ 159$ (a) (1976), codifies the majority-rule principle: "Representatives designated or selected for the purposes of collective bargaining by the majority of the employees in a unit appropriate for such purposes, shall be the cxclusive representatives of all the einployees in such unit for the purposes of collective bargaining . . . " Id. $\$ 159$ (a).

5. The two basic policies underlying the Act are stated succinctly in the concluding paragraph of section 1:

It is declared to be the policy of the United States to eliminate the causes of certain substantial obstructions to the free fiow of commerce and to mitigatc and eliminate these obstructions when they liave occurred by encouraging the practice and procedure of collective bargaining and by protecting the exercise by workers of full freedom of association, self-organization, and designation of representatives of their own choosing, for the 
balancing these two competing policy considerations. ${ }^{6}$ This comment examines the Board's balancing in the context of an employer's refusal to bargain with an incumbent union ${ }^{7}$ that the employer has recognized for at least one year. ${ }^{8}$ This comment argues that the Board has maximized industrial stability at the expense of employee free clioice by placing an unduly heavy burden on the employer to prove that the incumbent union no longer commands the inajority support of the employee unit. The employer is the party least able to bear this burden; therefore the union, and not the employer, should be the party obligated to prove majority status.

The imcumbent-union situation highlights the conflict between free choice and stability. When industrial stability is favored over employee free choice, incumbent unions becoine more entrenched even if they are not supported by a majority of unit employees. This result is contrary not ouly to the goal of employee free choice, but also to the language of the Act.9 The Board's current standard requires employers to disprove the majority status of mcunibent umions. Employers should have to prove only a good-faith doubt of the incumbent umon's inajority status, not an actual loss of majority support. Once the employer has shown a good-faith doubt, the umion should be required to prove its majority status to preserve continued employer recognition.

\section{The Evolution of the Good-Faith-Doubt Test}

Over the years the Board has struggled to develop clear standards to guide employers in their relationship with imcunibent unions. The issue confrontimg the Board is under what circumstances an employer can discontimue his bargaining relationship with an incumbent union

purpose of negotiating the terms and conditions of their employment or other mutual aid or protection.

Id. $\S 151$.

6. See id. $\$ 153$.

7. In this comment the term "incumbent union" means a union that the employer already has recognized as the exclusive bargaining representative of the employee unit.

8. The standards governing an employer's refusal to bargain with a union during the union's initial year of recognition differ from those employed by the Board after that period. See notes 14-20 infra and accompanying text.

9. See note 4 supra. Section 9(a) of the Act, 29 U.S.C. \& 159(a) (1976), can be read narrowly to mean that once a majority of unit employees "select or designate" the union, the umion need not command majority support. This static intcrpretation, which fails to take imto aecount changes in circumstance, renders employees' section 7 rights ineaningless once the employees select a union. The better interpretation recognizes that, except in limitcd situations, bargaining representatives must command inajority support. For a discussion of the limited situations in which the union should not have to show majority support, see notes 115-21 infra and aecompanying text. 
without violating sections $8(a)(5)^{10}$ and $8(a)(1)^{11}$ of the Act. Inconsistent Board decisions and conflicting court decisions evidence the disagreement over this issue.

Celanese Corp. of America ${ }^{12}$ represents one of the Board's earliest attempts to formulate explicit guidelines in this context. In Celanese the einployer refused to bargain with a union that had been certified in a Board-conducted election as the exclusive bargaining representative of the employee unit. The election had occurred over three years before the refusal to bargain, and the employer argued that the union had since lost its majority support. To justify his contention, the employer pointed to the significant reduction in the size of the bargaining unit since the certification. ${ }^{13}$ In response to the employer's refusal to bargain, the union filed charges with the Board alleging violations of sections $8(a)(5)$ and $8(a)(1)$ of the Act.

First, the Board reviewed the primciples applicable to a union whose certification is less than a year old. During the one-year certification period the union is presumed conclusively to command inajority support; ${ }^{14}$ absent unusual circunistances, ${ }^{15}$ the einployer must bargain with the union for at least one year, even if the union loses its n1ajority status. Then the Board held that the presumption continues after the one-year period, but becoines rebuttable. ${ }^{16}$ To rebut the presuniption,

10. 29 U.S.C. $\$ 158(a)(5)$ (1976). Section 8(a)(5) makes it an unfair labor practice for an employer to refuse to bargain with the representative of a majority of employees within the bargaining unit.

11. Id. § 158(a)(1). Section 8(a)(1) makes it an unfair labor practice for an employer "to mterfere with, restrain, or coerce employees in the exercise of the rights guaranteed in section 7." Id. See note 3 supra. Any violation of sectious 8(a)(2)-(5), 29 U.S.C. $\$ \$ 158(\mathrm{a})(2)-(5)(1976)$, is also a derivative violation of section $8(a)(1)$.

12. 95 N.L.R.B. 664 (1951).

13. Id at 670 . The reduction in unit size occurred during an economic strike called by the union. While many of the employees were on strike, the employer updated his production methods, thereby eliminating a nuniber of unit jobs, and hired an imdependent contractor to perform other unit work.

14. Id. at 671-72. Celanese involved a union that had been certified in a Board-conducted election. Such an election is not the sole method through which a union can obtain recognition from the employer. The employer may voluntarily recognize a union that is supported by a majority of the employees in the bargaining unit. The irrebuttable presunuption of majority support, known as the "certification-year rule," apphes to uncertified unions for a "reasonable period," usually one year. The Supreme Court approved the certification-year rule in Brooks v. NLRB, 348 U.S. 96 (1954).

15. "Unusual circumstances" have been found only: (1) when a union has become defunct, (2) when a schism has developed within the union, and (3) when there has been a rapid fiuctuation in the size of the bargaining unit. See Seger, The Majority Status of Incumbent Bargaining Representatives, 47 TUL. L. REv. 961, 966-78 (1973).

16. 95 N.L.R.B. at 672 . The rebuttable presumption of majority support establishes a prima facie case that an employer must bargain with an incumbent union. Terrell Mach. Co., 173 N.L.R.B. 1480, 1480 (1969), enforced, 427 F.2d 1088 (4th Cir.), cert. denied, 398 U.S. 929 (1970). 
the employer must show a good-faith belief that the union has lost its majority status:

[W] hether the [employer] violated Section 8(a)(5) . . depends, not on whether there was sufficient evidence to rebut the presumption of the Union's continuing majority status or to demonstrate that the Umion in fact did not represent the majority of the employees, but upon whether the Employer in good faith believed that the Union no longer represented the majority of the employees. ${ }^{17}$

Whether the employer has shown sufficient good-faith doubt in a particular case depends on the circunistances. ${ }^{18}$ In Celanese, however, the Board identified two essential considerations: (1) the employer must have a reasonable basis in fact for doubting the union's majority status, ${ }^{19}$ and (2) the employer cannot refuse to bargain with a union when the employer has committed unfair labor practices that undermine the union's majority support. ${ }^{20}$ The Board in Celanese held that the employer had satisfied the good-faith-doubt standard and found no reason to inquire into the union's actual inajority status. ${ }^{21}$ The einployer was therefore under no duty to bargain with the union until the union could again demonstrate majority support.

The dissentimg Board members in Celanese argued that an employer's good-faith doubt is irrelevant and that the issue should be whether the union actually enjoys majority status. ${ }^{22}$ This reasoning was not long ignored, and in Stoner Rubber Co. ${ }^{23}$ the Board inodified its approach. In Stoner the employer refused to bargain two inonths after the union's certification year had expired. The employer claimed that the union no longer commanded majority support. The employer gave several reasons for his contention: the union had won the certifi-

The presumption applies equally to certified and voluntarily recognized unions. Bartenders, Hotel, Motel \& Restaurant Employers Bargaining Ass'n, 213 N.L.R.B. 651 , $651-52$ (1974).

17. 95 N.L.R.B. at 671 (einphasis in original).

18. Id. at 673 .

19. Id. The term "good-faith doubt" is a misnomer, because the standard is objective as well as subjective. A more appropriate term would be "good-faith-reasonable doubt." The Board and the courts lave used the term "good-faith doubt" though recognizing the objective component of the test. This comment will do likewise.

20. This is the antithesis of good faith. The employer may not undermine the union's majority status through his own unfair labor practices and then defend against a section 8(a)(5) charge, 29 U.S.C. \& 158(a)(5) (1976), by alleging the union's loss of majority support. NLRB v. Little Rock Downtowner, Inc., 414 F.2d 1084, 1091 n.4 (8th Cir. 1969); see Franks Bros. v. NLRB, 321 U.S. 702 (1944).

21. 95 N.L.R.B. at 675 .

22. The dissent stated: "Certainly it does not follow from the fact that one las the right to rebut a presuniption by showing that a different status obtains, that it is sufficient to overcome the presumed status to show that one has good faith doubts as to the truth of the presumption." II. (Houston \& Murdock, Members, dissenting in part) (emplasis in original).

23. 123 N.L.R.B. 1440 (1959). 
cation election by only five votes; several employees had complained about the union; no negotiating had taken place for five inonths in the wake of an economic strike; and only eighteen former strikers and eighteen permanent strikers' replaceinents remained to operate the plant. ${ }^{24}$

The Board in Stoner reconsidered its approach to the issue of an incumbent union's majority status:

Proof of majority is peculiarly within the special competence of the union. It may be proved by signed authorization cards, dues checkoff cards, membership lists, or any other evidentiary means. An employer can hardly prove that a union no longer represents a majority simce he does not have access to the union's membership hists and direct interrogation of employees would probably be unlawful as well as of dubious validity. Accordingly, to overcome the presumption of majority the employer need only produce sufficient evidence to cast serious doubt on the union's continued nuajority status. The presumption then loses its force and the General Counsel must come forward with evidence that on the refusal-to-bargain date the union in fact did represent a majority of employees in the appropriate unit. ${ }^{25}$

The Board dismissed the umion's coinplaint because the einployer had produced sufficient evidence to rebut the presumption of majority support and the Board's General Counsel, aided by the umion, had not attempted to prove actual majority status. ${ }^{26}$

The effect of proving good-faith doubt distinguishes Celanese and Stoner. Under Celanese, good-faith doubt is a complete defense to an unlawful refusal-to-bargain charge. ${ }^{27}$ Under Stoner, however, a showing of good-faith doubt inerely rebuts the union's presumption of majority support, coinpelling the General Counsel to prove actual 1najority status. ${ }^{28}$ These differing standards affect the employer's evidentiary burden. Theoretically, the einployer's burden is the same under both standards: to prove good-faith doubt. But in practice the Board has placed a stronger evidentiary burden on the employer under

24. $I d$ at 1442 .

25. Id. at 1445 (emphasis in original).

26. Id. at 1446. The Board and the courts have held that the terms "good-faith doubt" and "serious doubt" are identical in meaning. See NLRB v. Vegas Vic, Inc., 546 F.2d 828, 829 (9th Cir. 1976), cert. denied, 434 U.S. 818 (1977); Orion Corp. v. NLRB, 515 F.2d 81, 85 (7th Cir. 1975); Bartenders, Hotel, Motel \& Restaurant Employers Bargaining Ass'n, 213 N.L.R.B. 651, 653 (1974). The Stoner case, however, signaled a significant reduction in the amount of evidence required from the employer to show good-faith doubt.

27. See text accoinpanying note 17 supra.

28. See text accompanying note 25 supra. 
the Celanese standard. ${ }^{29}$ Board decisions suggest that this burden is now so heavy that in effect, the einployer inust affirmatively prove the union's loss of inajority status. ${ }^{30}$ Under Stoner, however, the issues of majority support and good-faith doubt are separate. If the employer first shows good-faith doubt, the General Counsel, on behalf of the union, then bears the burden of proving majority status. ${ }^{31}$

Recent Board decisions have moved away from the Stoner rationale in favor of the Celanese approach. Under current Board standards good-faith doubt is a complete defense to a refusal-to-bargain charge, though the employer's burden of showing good-faith doubt is heavy. In Automated Business Systems, ${ }^{32}$ for example, the Board expressly repudiated the portion of Stoner that held that a showing of good-faith doubt is not a complete defense to a refusal-to-bargain charge. ${ }^{33}$ More

29. See, e.g., Pennco, Inc., 250 N.L.R.B. 716 (1980); Tahoe Nugget, Inc., 227 N.L.R.B. 357 (1976), enforced, 584 F.2d 293 (9th Cir. 1978), cert. denied, 442 U.S. 921 (1979).

30. See Guerdon Indus., Inc., 218 N.L.R.B. 658, 664 (1975) (Kennedy, Member, dissenting) (the Board's standard places an impossible burden upon the employer to prove a negative); $R$. Gorman, Basic Text on Labor Law: Unionization and Collective Bargaining 114 (1976) ("a Board finding that the doubt is supportable is generally tantamount to a finding that the union did not in fact have majority support").

In a recently filed petition for certiorari, the attorneys for the employer framed one of their questions substantially as follows: May the NLRB establish a rebuttable presunption to which it gives mere hip service and that in actual practice is an absolute and irrebuttable presumption resulting in a denial of due process? Silver Spur Casino v. NLRB, 49 U.S.L.W. 3446 (U.S. Oct. 11, 1980) (No. 80-660) (petition for certiorari), cert. denied, 101 S. Ct. 1973 (1981).

31. See text accompanying note 25 supra.

32. 205 N.L.R.B. 532 (1973), enforcement denied, 497 F.2d 262 (6th Cir. 1974).

33. The Board's treatinent of its previous holding in Stoner was blunt:

[T] f. . Stoner Rubber were taken hiterally, it would mean that even where an employer demonstrates a reasonably based doubt of the union's continuing majority . . . he will have violated Section 8(a)(5) if the General Counsel is able to prove that the majority in

fact continued. That would indeed be a major departure from existing law.

Id. at 535 (footnote omitted). The last sentence is curious because the Board had never expressly overruled Stoner and had recently followed it in Taft Broadcasting, 201 N.L.R.B. 801 (1973).

Current Board decisions still use the term "good-faith doubt," and hold that a showing of good-faith doubt rebuts the presuinption of majority support. See Pennco, Inc., 250 N.L.R.B. 716 (1980). Considering that good-faith doubt also is held to be a complete defense to a refusal-to -bargain charge, the contradiction in the Board's approach is immediately apparent. To say that good-faith doubt is both a complete defense to a refnsal-to-bargain charge and that it also rebuts the presunption of majority support means that a complete defense to a refusal-to-bargain charge is made out by merely rebutting the presumption of majority support. The Federal Rules of Evidence provide, however, that once a presuinption is rebutted a complete defense is not made out; rather, the opposing party must satisfy its burden of proof. FED. R. EvID. 301 states that:

[A] presunption imposes on the party against whom it is directed the burden of going forward with evidence to rebut or meet the presumption, but does not shift to such party the burden of proof in the sense of the risk of nonpersuasion, which remains throughout the trial upon the party on whom it was originally cast.

29 U.S.C. $\$ 160$ (b) (1976) requires the Board to apply the Federal Rules of Evidence "so far as practicable" in unfair labor practice proceedings. It has been argued correctly that the Board's current standard is not in accord with Rule 301. See Note, NLRB Determination of Incumbent 
recently, in Pennco, Inc. ${ }^{34}$ the Board justified the employer's heavy evidentiary burden as necessary to effectuate the dual pohicies of industrial stability and employee free choice. ${ }^{35}$

-The Stoner and Celanese approaches also differ sharply in their treatment of the employer's evidence. The employer's evidence is probative under the Stoner approach if it tends to show that the einployer has a good-faith doubt about the union's inajority support. Under $\mathrm{Ce}$ lanese, though the "good-faith doubt" language is used, evidence tending to show good-faith doubt is not probative unless it also tends to prove actual loss of inajority support. This distinction explams the disparate treatment the courts of appeals accord employers.

\section{The Split Among the Courts of Appeals on the GOOD-FAITH-DOUBT ISSUE}

Most courts have adopted the Stoner language that actual majority status, rather than good-faith doubt, is the ultimate issue. ${ }^{36}$ Some of these courts, however, place an evidentiary burden on the einployer that is more in accordance with Celanese, despite their ostensible adherence to Stoner. ${ }^{37}$

Unions' Majority Status, 54 IND. L.J. 651, 660-61 (1979). The Board could alleviate a great deal of confusion by stating explicitly that the good-faith-doubt standard is merely a device to shift the ultimate burden of proof to the employer.

34. 250 N.L.R.B. 716 (1980).

35. The Board stated that "in light of the dual policies underlying the presumption, the employer's burden is a heavy one." Id. at 717. It described the dual policies as follows:

The presumption of continuing majority status essentially serves two important functions of Federal labor policy. First, it promotes continuity im bargaining relationships .... The resulting imdustrial stability remains a primary objective of the Wagner Act, and to an even greater extent, the Taft-Hartley Act . . . Second, the presumption of continuing majority status protects the express statutory right of employees to designate a collective bargaining representative of their own choosing, and to prevent an employer from impairing that right without some objective evidence that the representative the employees have designated no longer enjoys majority support.

Id. at 716-17.

36. E.g., Bellwood Gen. Hosp., Inc. v. NLRB, 627 F.2d 98, 102 (7th Cir. 1980); NLRB v. Silver Spur Casino, 623 F.2d 571, 577 (9th Cir. 1980), cert. denied, 101 S. Ct. 1973 (1981); W \& W Steel Co. v. NLRB, 599 F.2d 934, 939 (10th Cir. 1979); National Car Rental Sys., Inc. v. NLRB, 594 F.2d 1203, 1207 (8th Cir. 1979); Automated Business Syss. v. NLRB, 497 F.2d 262, 269-72 (6th Cir. 1974); Lodges 1746 \& 743, Int'1 Ass'n of Machinists \& Aerospace Workers v. NLRB, 416 F.2d 809, 812 (D.C. Cir. 1969), cert. denied, 396 U.S. 1058 (1970). Contra, NLRB v. Dayton Motels, Inc., 474 F.2d 328, 331 (6th Cir. 1973). The courts may feel compelled to follow Stoner because of the constraints imposed upon thein by FED. R. EviD. 301, which provides expressly that a presumption does not alter the burden of proof. See note 33 supra.

37. See NLRB v. Silver Spur Casino, 623 F.2d 571, 579 (9th Cir. 1980), cert. denied, 101 S. Ct. 1973 (1981); NLRB v. Tahoe Nugget, Inc., 584 F.2d 293, 297 (9th Cir. 1978) (evidence must be "clear, cogent, and convincing"), cert. denied, 442 U.S. 921 (1979); J. Ray McDermott \& Co. v. NLRB, 571 F.2d 850, 858-59 (5th Cir.) (evidence tested by a high standard of objectivity), cert. denied, 439 U.S. 893 (1978); Retired Persons Pharmacy v. NLRB, 519 F.2d 486, 489-90 (2d Cir. 
Two recent cases highlight this dichotomy. In each case the Board held that the employer failed to prove good-faith doubt, and entered a bargaining order. ${ }^{38}$ In NLRB v. Tahoe Nugget, Inc. ${ }^{39}$ the employer based his claim of good-faith doubt on employee statements of discontent with the union, ${ }^{40}$ a high employee turnover rate, ${ }^{41}$ a lack of union activity in processing grievances, ${ }^{42}$ other evidence of union mactivity, ${ }^{43}$ a low rate of union membership, ${ }^{44}$ union financial difficulties, ${ }^{45}$ a good bargaining history between the union and the employer, ${ }^{46}$ and union admissions of lack of membership. ${ }^{47}$

The Court of Appeals for the Ninth Circuit held that the evidence was insufficient to prove the employer's claim of good-faith doubt, remarking that no single item clearly showed a decline in umon support. 48 The court considered evidence of employee statements of dissatisfaction too ambiguous to support a finding of good-faith doubt. This conclusion accords with prior Board decisions. ${ }^{49}$ Similarly, the

1975) (employer must be prepared to meet a high standard of proof). The Board's findings of fact are conclusive "if supported by substantial evidence on the record considered as a whole." 29 U.S.C. § 160(e) (1976). The courts therefore are constrained in their judicial review of Board findings of fact. Some courts, however, have followed the Stoner approach and have more readily demied enforcement of Board orders. See Bellwood Gen. Hosp., Inc. v. NLRB, 627 F.2d 98 (7th Cir. 1980); W \& W Steel Co. v. NLRB, 599 F.2d 934 (10th Cir. 1979); National Car Rental Sys., Inc. v. NLRB, 594 F.2d 1203 (8th Cir. 1979).

38. Bellwood Gen. Hosp., Inc., 243 N.L.R.B. 88 (1979), enforcement denied, 627 F.2d 98 (7th Cir. 1980); Tahoe Nugget, Inc., 227 N.L.R.B. 357 (1976), enforced, 584 F.2d 293 (9th Cir. 1978), cert. denied, 442 U.S. 921 (1979).

39. 584 F.2d 293 (9th Cir. 1978), cert. denied, 442 U.S. 921 (1979).

40. Id. at 305-06. Most of these statements were remarks, overheard by the employer's manager, that the union could do nothing for the employees. 227 N.L.R.B. 359, 361 (1976) (decision of administrative law judge, which the Board adopted). In Nevada Lodge, a case consolidated with Tahoe Nugget, the employee statements were more akin to direct repudiations of the union. Some employees stated to the employer's general manager that they were uninterested in and unconcerned with the union. Id. at 371 .

41. 584 F.2d at 306. In Tahoe Nugget the turnover rate was $80 \%$ per year. 227 N.L.R.B. at 366. In Nevada Lodge the rate was estimated at $100 \%$ per year. Id. at 376 .

42. $584 \mathrm{~F} .2 \mathrm{~d}$ at 307.

43. Id. Umion officials inspected the busmess premises infrequently and no employees attended a union meeting of employees in the Lake Tahoe area.

44. Id. The extent of union membership in the particular busmesses was unclear. A former union president testified that there were approximately 1000 union members out of approximately 30,000 employees in the Lake Tahoe and Reno areas. 227 N.L.R.B. at 370.

45. $584 \mathrm{~F} .2 \mathrm{~d}$ at 307 . The union had been placed in trusteeship.

46. $Y$ d. at 307-08.

47. Id. at 308 .

48. $Y$ d.

49. See Pick-Mt. Laurel Corp., 239 N.L.R.B. 1257, 1261 (1979); Valley Nitrogen Producers, Inc., 207 N.L.R.B. 208, 214 (1973). But see Hayworth Roll \& Panel Co., 130 N.L.R.B. 604, 606 (1961) (the Board considered employee expressions of dissatisfaction over paying dues as evidence supporting good-faith doubt). See also NLRB v. Top Mfg. Co., 594 F.2d 223, 224-25 (9th Cir. 1979). 
court considered the high turnover rate too equivocal to support a finding of good-faith doubt. The court followed established Board precedent in applying the "ancillary-ratio presumption": that new einployees support the umion in the saine ratio as those they replace. ${ }^{50}$ The court also followed the traditional Board approach of rejecting evidence of umion inactivity, ${ }^{51}$ noting that no testimony indicated that there were grievances that the union should have processed.52 The evidence of low union affiliation was deemed only marginally relevant because it was never tied to the particular units of employees in question. ${ }^{53}$ The court agreed with the Board's basic premise that union membership is not equivalent to union support because einployees may desire union representation but refuse to support the union

50. Laystrom Mfg. Co., 151 N.L.R.B. 1482, 1484 (1965), enforcement denied on other grounds, 359 F.2d 799 (7th Cir. 1966). The Board relies on the ancillary-ratio presumption to maintaim industrial stability, probably surmising that without the presumption majority status constantly would be open to attack after the certification year. Courts have used this presumption when the employee turnover occurred in the normal course of busmess. See Sahara-Tahoe Corp. v. NLRB, 581 F.2d 767, 771-72 (9th Cir. 1978), cert. denied, 442 U.S. 917 (1979); NLRB v. Little Rock Downtowner, Inc., 414 F.2d 1084, 1091 (8th Cir. 1969); NLRB v. John S. Swift Co., 302 F.2d 342, 345 (7th Cir. 1962). Some courts, however, lave found that evidence of employee turnover tends to prove good-faith doubt. See NLRB v. Alvin J. Bart \& Co., 598 F.2d 1267, 1271 (2d Cir. 1979) (11 out of 14 employees replaced); Dalewood Reliabilitation Hosp., Inc. v. NLRB, 566 F.2d 77, 80 (9th Cir. 1977) ( $90 \%$ employee turnover); National Cash Register Co. v. NLRB, 494 F.2d 189, 195 (8th Cir. 1974) (32\% employee turnover).

Only in the most extreme circumstances will the Board consider evidence of employee turnover as probative of good-faith doubt. For instance, the Board has applied the ancillary-ratio presumption to strikers' replacements, thereby concluding that strikers' replaccments support the union in the same ratio as the employees who are out on strike. See Pennco, Inc., 250 N.L.R.B. 716 (1980); Burbington Hoines, Inc., 246 N.L.R.B. No. 165, 103 L.R.R.M. 1116 (Dec. 14, 1979); Servomation, Inc., 235 N.L.R.B. 975, 978 (1978). The Court of Appeals for the Eighth Circuit has criticized the application of this presumption to strikers' replaccments as "not specifically authorized by statute" and "far from reality." National Car Rental Sys., Inc. v. NLRB, 594 F.2d 1203, 1206 (8th Cir. 1979). The Court of Appeals for the Second Circuit has lield, however, that the Board's application of the presumption to strikers' replacements is justified. See NLRB v. Windham Community Memorial Hosp., 577 F.2d 805, 814 (2d Cir. 1978). But see Note, The Strikers' Replacements Presumption and an Employer's Duty to Bargain with the Incumbent Union, 21 B.C.L. REv. 455 (1980).

51. The courts lave considered evidence of union mactivity to support good-faith doubt more readily than the Board. See Pioneer Inn Assocs. v. NLRB, 578 F.2d 835, 839-40 (9th Cir. 1978) (evidence of union inactivity considered but rejected as too weak); Printing Pressmen \& Offset Workers Local 51 v. NLRB, 575 F.2d 1045, 1049 (2d Cir. 1978) (evidence of the union's failure to police the union-security provision of the collective bargaining agreement for seven to nine months supported good-faith doubt); Burns Int'1 Security Servs., Inc. v. NLRB, 567 F.2d 945, 947 (10th Cir. 1977) (that only one grievance was filed in a one-year period was considered as evidence). But see Viking Lithographers, Inc., 184 N.L.R.B. 139, 139 (1970) (total lack of union activity for four months supported good-faith doubt).

52. NLRB v. Tahoe Nugget, Inc., 584 F.2d 293, 307 (9th Cir. 1978), cert. denied, 442 U.S. 921 (1979).

53. Id. See note 44 supra. 
financially. ${ }^{54}$ Likewise, the union's financial difficulties and the employer-union bargaining history were considered only equivocal evidence of loss of support.55 Finally, the court found that the union's admissions of lack of meinbership were not damaging to the union's position because the admissions concerned only union meinbership, not union support. 56 Because the court was unable to find any single itein clearly showing a decline in union support, ${ }^{57}$ it held that the evidence was insufficient to prove good-faith doubt.

The Tahoe Nugget court apparently expected the einploycr to prove the union's actual loss of inajority status, not merely its own good-faith doubt. ${ }^{58}$ All of the evidence the court considered, both indi-

54. See Servomation, Inc., 235 N.L.R.B. 975,978 (1978); United Supermarkets, Inc., 214 N.L.R.B. 958, 958 (1974) ("that less than a nrajority of the unit employees may have authorized dues checkoffs is immaterial to the issue of majority status"); Terrell Mach. Co., 173 N.L.R.B. 1480, 1481 (1969), enforced, 427 F.2d 1088 (4th Cir.), cert. denied, 398 U.S. 929 (1970).

A former Board member criticized this premise as "ascribing a free rider mentality to the majority of the American workmen." Guerdon Indus., Inc., 218 N.L.R.B. 658, 664 (1975) (Kennedy, Member, dissenting). Although many courts have agreed with the Board, e.g., Retired Persons Pharmacy v. NLRB, 519 F.2d 486, 491 (2d Cir. 1975); Terrell Mach. Co. v. NLRB, 427 F.2d 1088, 1090 (4th Cir.), cert. denied, 398 U.S. 929 (1970); NLRB v. Gulfmont Hotel Co., 362 F.2d 588, 592 (5th Cir. 1966), some courts have considered evidence of low union nuembership, at least when conbined with other evidence. See, e.g., NLRB v. Triplett Corp., 619 F.2d 586 (6th Cir. 1980); Star Mfg. Co., Div. of Star Forge, Inc. v. NLRB, 536 F.2d 1192 (7th Cir. 1976); National Cash Register Co. v. NLRB, 494 F.2d 189 (8th Cir. 1974).

The Board will consider evidence of low union membership when there has been a drastic reduction in dues checkoffs by the enployecs in the unit. E.g., Convair Div. of Gen. Dynamics Corp., 169 N.L.R.B. 131, 134-35 (1968) (sudden decrease in checkoffs fron1 $36 \%$ to $26 \%$ of einployees). A large group of employees probably would simultaneously stop paying dues only if they collectively were repudiating the union as their bargaining representative.

55. NLRB v. Tahoe Nugget, Inc., 584 F.2d 293, 307-08 (9th Cir. 1978), cert. denied, 442 U.S. 921 (1979).

56. Union statements of lack of support may in soine cases be determinative of the issue of good-faith doubt. If a union official admits that the union no longer commands majority support, this admission may be enough to prove good-faith doubt. See Lodges 1746 \& 743, Int'1 Ass'n of Machinists \& Aerospace Workers v. NLRB, 416 F.2d 809, 812-13 (D.C. Cir. 1969) (admission of union's attorney considered important evidence showing good-faith doubt), cert. denied, 396 U.S. 1058 (1970).

Problems of ambiguity, however, are prevalent in this context. In Harvey's Wagon Wheel, Inc., 236 N.L.R.B. 1670 (1978), enforced, 640 F.2d 274 (D.C. Cir. 1980), for example, a union official had stated that the union was "in trouble." The Board commented as follows: "[A] renuark of [this] type . . . is not an admission that the Union no longer represented a nuajority of unit employees. . . . Its implication is, at most, an admission of financial difficulties and difficulties in the collection of dues." Id. at 1671 n.3 (citation omitted).

57. NLRB v. Tahoe Nugget, Inc., 584 F.2d 293, 308 (9th Cir. 1978), cert. denied, 442 U.S. 921 (1979). The court stated: "Sonte of the evidence is subjective; the inferences of loss of Union support are ambiguous. Before unilaterally disrupting the bargaining relationship, an employer inust obtain more rehable evidence of lost support." Id.

58. The language the court used supports this position. The court searched for evidence that was "clearly referable to a loss of support," $i d$, rather than evidence tending to provide a reasonable basis to doubt the union's majority status. See Sahara-Tahoe Corp. v. NLRB, 648 F.2d 553, 
vidually and cumulatively, may have been only inarginally probative of actual loss of support. The evidence did, however, have inore probative value on the issue of good-faith doubt. If the court had used the employer's evidence to decide only this issue, the cumulative weight of all the evidence would have been substantial. It is certainly possible that the employer in Tahoe Nugget reasonably and in good faith doubted that the umion had majority support. The Tahoe Nugget court and the Board opted for the Celanese approach, however, interpreting the good-faith-doubt test to require the einployer to disprove actual inajority status. 59

In contrast, the Court of Appeals for the Seventh Circuit, in Bellwood General Hospital, Inc. v. NLRB ${ }^{60}$ carefully distinguished the good-faith-doubt test froin the issue of actual inajority status. The Bellwood court considered evidence similar to that presented by the enployer in Tahoe Nugget. The einployer sought to establish good-faith doubt based on a seventy-percent einployee turnover rate since certification, employee stateinents of dissatisfaction with the union, absence of properly elected union officers, low attendance at union ineetings, lack of grievance activity, and the union's failure to have representatives visit the hospital or to use a bulletin board that the hospital provided.61

557 (9th Cir. 1980) ("before refusing to bargain with a union, an employer should have before it evidence which unequivocally indicates that the union no longer has the majority support of the employees"), cert. denied, 101 S. Ct. 2317 (1981). Concededly, there is room for argument that the court was using the good-faith-doubt test, albeit in a highly objective manner. Holding an employer to an impossible standard of objectivity is no better than expecting him affirmatively to prove loss of support. The Tahoe Nugget court failed to recognize that the employer was not in a position to come forward with better evidence. Courts must view the strength of the employer's evidence in light of the employer's himited access to evidence of loss of support.

59. Although generally the Court of Appeals for the Ninth Circuit has followed the Board's approach, the court has expressed reservatious. In NLRB v. Silver Spur Casimo, 623 F.2d 571 (9th Cir. 1980), cert. denied, 101 S. Ct. 1973 (1981), the court, while enforcing the Board's bargaining order, recognized that the Board may have made the presumption of majority support too difficult to rebut. 623 F.2d at 581. In Dalewood Rehabilitation Hosp., Inc., v. NLRB, 566 F.2d 77 (9th Cir. 1977), the court refused to enforce the Board's bargaining order, finding that it was not supported by "substantial evidence considering the record as a whole." Id. at 80.

60. 627 F.2d 98 (7th Cir. 1980).

61. Id. at 103-04. The variety of evidence that an employer can provide produces complex situations which the Board must weigh in accordance with its standards. The evidence did not materially differ in Bellwood and Tahoe Nugget; the Board imposed a bargaining order in both cases. The cases turn on the differing approaches of the two courts.

In considering the problem of weighing different evidence, the Court of Appeals for the District of Columbia Circuit explained that "[t]he problem with this case-by-case approach is that both the employer and the Union are subject to the shifting views of the members of the Board and the courts as to what evidence is sufficiently 'objective' and convincing to demonstrate a good faith doubt." Peoples Gas Sys., Inc. v. NLRB, 629 F.2d 35, 43 (D.C. Cir. 1980). The court further stated that "[a] standard under which such small factual differences are decisive seems question- 
Rather than use the analysis suggested by Tahoe Nugget, the Bellwood court adopted an approach closer to Stoner. Throughout its analysis the Bellwood court distinguished between proving good-faith doubt and proving actual loss of support. This approach enabled the employer's evidence to accumulate substantial weight: ${ }^{62}$

Even were we to agree ... that some of the imdividual elements might not, in themselves, justify a good faith doubt, or even that the sum total of the evidence might not support a finding that the Union had, in fact, lost its majority status . . . we think the record without reasonable dispute indicates that the Hospital had sufficient objective evidence before it on which to base a reasonable doubt of the Union's continued majority support. The Hospital's presentation was sufficient, at least, to shift the burden to the General Counsel to establish the Union's majority. ${ }^{63}$

Thus, although the evidence in the two cases was strikingly similar, the Bellwood court reached the opposite result froin Tahoe Nugget and refused to enforce the Board's bargaining order. ${ }^{64}$

The approach taken in Stoner and Bellwood is preferable to that used in Celanese and Tahoe Nugget. The policies underlying the Act are best effectuated if the Board and the courts decide whether an incumbent union has in fact retained its inajority status. This approach places the ultimate burden of proof on the party best situated to bear it, so that the Board, as the trier of fact, is aided in its determination of the majority-status issue. The Board's current approach of placing a heavy burden on the einployer to prove what it calls good-faith doubt nay result in the Board ordering an einployer to bargain with a minority umion, merely because the einployer is unable to prove that the umion lacks majority support. This result does not strike the balance between the goals of employee free choice and industrial stability that the Act conteinplates.

able when an ultimate finding of an unfair labor practice and a resultant bargaining order have such important consequences for the employees' section 7 rights." Id. at 43 n.14.

62. The Tahoe Nugget court also endorsed a "cumulative" approach to the evidence. NLRB v. Tahoe Nugget, Inc., 584 F.2d 293, 305 (9th Cir. 1978), cert. denied, 442 U.S. 921 (1979). The court was unable to apply this approach, however, because it did not focus on the employer's good-faith doubt. Instead, it focused on whether there was an actual loss of majority support. The cumulative weight of all of the evidence was therefore so low that it made hittle difference whether the court classified its approach as "cumulative."

63. $627 \mathrm{~F} .2 \mathrm{~d}$ at 104 (citations oumtted).

64. Id. at 105 . 


\section{Policy Considerations}

A. Employee Free Choice.

The Board mamtaims that when an employer unilaterally terminates the bargaining relationship with an imcumbent union he abrogates the employees' statutory right to choose their bargaining representative. 65 The Board reasons that employees who are dissatisfied with their representation have other remedies at their disposal. ${ }^{66}$ Any time after the certification year, employees can file a decertification petition alleging that the union is no longer supported by a majority of the employees. ${ }^{67}$ If at least thirty percent of the employees in a bargaining unit sign the petition, the Board conducts a decertification election to determine whether the union has majority support. ${ }^{68}$

Reliance on the decertification procedure implicitly assunes that such a petition is always an effective remedy for the employees. But filing a petition, and mustermg the requisite thirty percent showing of interest, requires employee organization and imitiative, as well as knowledge that the procedure is available. In addition, most einployees naturally seek to avoid falling into the incumbent union's disfavor, which is the probable result of actively trying to oust the union. Thus, the decertification election renedy is useful only in those cases in which the einployees are knowledgeable, organized, concerned and courageous; it is therefore not sufficient by itself to safeguard the einployees' right of free choice. Furthermore, the eniployer is in a much better position to challenge an incunbent union's majority status. The employer is likely to be aware of the available procedures, is obviously concerned with the union's support, and is probably not afraid to challenge the union.

65. See NLRB v. Tahoe Nugget, Inc., 584 F.2d 293, 301 (9th Cir. 1978) ("In refusing to bargain because of an alleged decline in union adherents, the employer is acting as vicarious champion of its employees, a role no one has asked it to assunie"), cert. denied, 442 U.S. 921 (1979); Pioneer Inn Assoc. v. NLRB, 578 F.2d 835, 840 (9th Cir. 1978) ("the Board may strike the balance more favorable toward the union when the union's status is challeged by the einployer rather than the einployees themselves"); Retired Persons Pharmacy v. NLRB, 519 F.2d 486, 491 (2d Cir. 1975) (the employer nust meet a high standard of proof).

66. See NLRB v. Silver Spur Casino, 623 F.2d 571, 578 (9th Cir. 1980), cert. denied, 101 S. Ct. 1973 (1981):

We have not failed to observe that ... the Board has favored continuity in the bargaining structure over the enhancement of employee free choice. However, the Board's [approach] . . . while not enhancing employee rights, does not adversely affect those rights. As always, the employees may exercise their freedom of choice by petitioning the Board for an election....

67. The employees' right to seek a decertification election is provided for in section 9(c)(1)(A)(ï) of the Act. 29 U.S.C. $\$ 159(c)(1)(A)(i)(1976)$.

68. See generally J. FeERICK, H. BAER \& J. ARFA, NLRB Representation ElectionsLAW, PRACTICE \& Procedure (1980). 
The Board also maintains that an employer who entertains serious doubts about the union's majority status after the certification year infringes less on einployee free choice if he files an election petition and continues to bargain instead of unilaterally terminating the bargaining relationship. ${ }^{69}$ An election can resolve the issue of majority status faster and more accurately. ${ }^{70}$ In United States Gypsum Co. ${ }^{71}$ however, the Board held that an employer inust show reasonable grounds for doubting the incumbent union's status before the Board will conduct an election at the employer's request. ${ }^{72}$ This standard has been interpreted as essentially equivalent to the good-faith-doubt test. ${ }^{73}$ An einployer therefore has no incentive to use the election procedure instead of simply refusing to bargain; the good-faith-doubt standard inust be satisfied in either case. If this were not so, the employer could harass the incunbent union by arbitrarily compelling it to prove its continued

69. Section 9(c)(1)(B) gives the employer the right to file an election petition that questions the imcumbent union's majority status after the certification year. 29 U.S.C. $§ 159(c)(1)(B)$ (1976).

70. Courts have suggested that an imcumbent union's majority status should be determined exclusively through elections rather than through unfair labor practice proceedings. Daisy's Originals, Inc. v. NLRB, 468 F.2d 493 (5th Cir. 1972) held that an employer should be entitled to an election in the incumbency context so long as he has satisfied the standards of NLRB v. Gissel Packing Co., 395 U.S. 575 (1969). The Gissel standards generally are applicable in the initial recognition, rather than the incumbency, situation. As elaborated in Linden Lunber Div., Summer \& Co. v. NLRB, 419 U.S. 301 (1974), Gissel holds that the employer does not have to recognize a umion initially unless the umion has proved its majority status in a Board-conducted election, so loug as the employer has not committed serious unfair labor practices that liave undermined the umion's support. Essentially, Daisy's Originals advocates an election at the employer's demand in the incumbency situation, so long as the employer has committed no significant unfair labor practices. The Daisy's Originals court explained that an election, rather than a bargaining order, is the preferred remedy for an uulawful refusal to bargain:

The remedy cliosen . . . must be primarily remedial as opposed to pumitive in nature ... and should not stand if it "is a patent attempt to achieve ends other than those whicl can fairly be said to effectuate the policies of the Act." . . In cases in which a bargaining order lias been deemed appropriate the employees liave been stripped of their $\$ 7$ right to refuse unionization in order to remedy the wrongdoings of their employer. The rationale of these cases lias been that the employees' loss of rights is only temporary (at a minimum of one year before a decertification petition can be filed.)

468 F.2d at 499 (citations omitted).

The Daisy's Originals court believed that although the facts of Gissel were dissimilar, the policy considerations were not. In NLRB v. Frick Co., 423 F.2d 1327, 1331 n.6 (3d Cir. 1970), the court reached the opposite conclusion: "In the Gissel type of situation, the emplrasis is on fulfilling the national labor policy of assuring employees a free clioice of representatives by the most reliable method. In the case of withdrawal of recognition, however, competing considerations of assuring the stability of an established bargaining relationship are involved."

For a suggestion that the Board apply the initial recognition standards in the imcumbency context, see Note, supra note 33.

71. 157 N.L.R.B. 652 (1966).

72. The employer must "demonstrate by objective considerations that it lias some reasonable grounds for believing that the union has lost its inajority status since its certification." Id. at 656.

73. See R. Gorman, supra note 30, at 110. 
majority status. ${ }^{74}$ The Board's current standards, however, actually discourage the employer from using the election procedure. Under $\mathrm{Ce}$ lanese a showing of good-faith doubt reheves the employer of his duty to bargam,75 whereas under Gypsum a showing of good-faith doubt merely entitles the employer to an election. ${ }^{76}$ So long as the Board discourages the use of employer election petitions they remain an insufficient safeguard of employee free choice.

The proposition that an employer impairs einployee free choice by terminating the bargaining relationship assumes that the incumbent umion coininands majority support. Whether the incumbent union commands such support is the very fact at issue in einployer challenges to majority status. If only a minority of the einployees support the incumbent union, an employer who terminates bargaining actually enhances employee free choice. ${ }^{77}$

In actuality the Board's current standard significantly infringes upon employee free choice. If the employer does not satisfy the good -faith-doubt test, the Board will order the employer to bargam with the incumbent umion. A bargaining order, however, implicitly directs the employees to maintain the incumbent umion as their bargaining representative. The Court of Appeals for the District of Columbia Circuit recently described the effect of a bargaining order on employees:

After a bargaining order is entered, there is a "reasonable period," similar to the year after a Union is initially certified, during which no decertification petition will be considered. Then, if a contract is signed, which seems likely to occur in the course of a year of bargaining, the three-year contract bar would stymie any attempt by the employees to choose another Union or decertify the present Union,

74. See Peoples Gas Sys., Inc. v. NLRB, 629 F.2d 35, 44 (D.C. Cir. 1980):

The danger of permitting an employer to disrupt bargaining and continuously challenge a Union's majority, diverting its attention and resources from representing the workers to defending itself, requires a different standard from the one which governs initial recognition. Obviously, an automatic right to insist on an election, the procedure approved in Linden Lumber for initial recognition cases, would not be appropriate in withdrawal of recognition cases.

75. See text accompanying note 17 supra.

76. Election issues are decided by the Regional Directors, rather than the Board. Regional Directors nuay apply a less stringent good-faith-doubt standard than the Board when an employer has followed the "better practice" of filing for an election, rather than refused to bargain. See Brooks v. NLRB, 348 U:S. 96, 104 n.18 (1954). Because of the significant number of employers who choose refusal to bargain over filing an election petition, however, the election standard probably is not materially different front the unfair labor practice standard.

77. NLRB v. Tahoe Nugget, Inc., 584 F.2d 293, 300 (9th Cir. 1978) ("If union support is lacking, the employer's action actually furthers the cause of employee deniocracy by overcoming the inertia which helps inaintain the status quo"), cert. denied, 442 U.S. 921 (1979). 
unless the Board were to provide for an exception to its normal rules. ${ }^{78}$

In contrast, the consequences of dismissing the union's refusal -to-bargam charge are not particularly burdensome to either the employees or the union. Under the current Board standard, if the employer proves a "good-faith doubt" of the union's majority status, he has no further duty to bargam with the union. The union is free, however, to atteinpt to reestabhish its majority support by traditional nethods. The union is in the same position as a union initially seeking to organize an employee umit. If the union can procure signatures indicating support from thirty percent of the employees, it is entitled to another certification election. ${ }^{79}$ Thus, erroneously deciding the majoritystatus issue in favor of the union effectively forces a minority union upon the employees, whereas dismissal nierely requires the union to reprove majority support.

Because a bargaining order has such miportant consequences for employee free choice, the Board should not enter an order unless it determines, by a preponderance of the evidence, that the mcunibent union has majority support. By placing the burden on the einployer to disprove the union's majority status, the Board creates the substantial possibility that a bargaming order will direct an einployer to barganı with a minority union, thereby contravening the statutory policy of einployee free choice. ${ }^{80}$ An employer is in a difficult, if not impossible, position to disprove an incumbent union's inajority status. ${ }^{81}$ First, the employer is required to prove a negative-that the union no longer commands inajority support. ${ }^{82}$ Second, as the Board explained in Stoner, "[p]roof of majority is peculiarly within the special competence of the union."83 The einployer has limited or no access to union files and records. Moreover, the employer places himself in an extremely

78. Peoples Gas Sys., Inc. v. NLRB, 629 F.2d 35, 45 n.17 (D.C. Cir. 1980) (citations omitted). Although the Board has stated that a bargaining order does not give rise to a presumption of majority support, Squirrel Brand Co., 104 N.L.R.B. 289, $290-91$ (1953), the order remains effective at least until its purpose, which is to remedy the antecedent refusal to bargain, has been achieved. Northwestern Photo Engraving Co., 106 N.L.R.B. 1067, 1068 (1953).

Significantly, unions may have the authority to enter into collective bargaining agreements without employee approval and therefore insulate themselves from attack of their majority status. See A. Cox, D. BoK \& R. Gorman, CASES and Materials on Labor Law 404 (8th ed. 1977) ("So far as individual employees are concerned, collective bargaining resembles the legislative process of a State or municipality").

79. 29 U.S.C. \& $159(\mathrm{c})(\mathbf{1})(\mathrm{A})(\mathrm{i})(1976)$.

80. See notes 3-4 supra and accompanying text.

81. Cf. NLRB v. Talioe Nugget, Inc., 584 F.2d 293, 301 (9th Cir. 1978) ("employer usually does have inferior access to the relevant information and may risk further penalty in garnering additional data"), cert. denied, 442 U.S. 921 (1979).

82. Guerdon Indus., Inc., 218 N.L.R.B. 658, 664 (1975) (Kennedy, Member, dissenting).

83. 123 N.L.R.B. 1440, 1445 (1959). See text accompanying note 25 supra. 
precarious position if he questions employees regarding their union sentiment. ${ }^{84}$ Such questioning is inherently repugnant to employee free choice and in many situations constitutes a violation of section 8(a)(1) of the Act. ${ }^{85}$ An employer cannot, for instance, lawfully conduct a poll of his employees to determine union sentiment unless the poll complies with stringent procedural safeguards ${ }^{86}$ and the einployer has a good -faith doubt concerning the union's majority status. ${ }^{87}$ Simce good-faith doubt is a prerequisite to conductimg a lawful poll, such a poll cannot be used to estabhish good-faith doubt im either an election or an unfair labor practice proceeding. An employer therefore is limited in the kinds of evidence he can generate to disprove the union's majority status; the evidence necessarily will be circumstantial and usually will be equivocal. ${ }^{88}$

Certain kinds of evidence enuployers regularly use to attempt to show good-faith doubt have been mentioned in connection with the Tahoe Nugget case: employee stateinents of dissatisfaction with the union, high rates of employee turnover, low union membership rates, union inactivity, and union admissions of lack of membership. ${ }^{89}$ The Board consistently has accorded little weight to this evidence, regarding it as too equivocal to prove good-faith doubt..$^{90}$ In addition, the ancillary presumptions apphied by the Board strip this kind of proof of any

84. See Bartenders, Hotel, Motel \& Restaurant Employers Bargaining Ass'n, 213 N.L.R.B. 651,657 (1974) (Kennedy, Member, dissenting) (it is legally indefensible for the Board to require the employer to produce evidence that he could have obtained only through unlawful interrogation).

85. See Struksnes Constr. Co., 165 N.L.R.B. 1062, 1067 (1967) ("any attempt by an employer to ascertain employee views and sympathies regarding unionism generally tends to cause fear of reprisal in the mind of the employee if he rephies in favor of unionism and, therefore, tends to infringe on his Section 7 rights").

86. Id at 1063. The Board held:

Absent unusual circumstances, the polling of employees by an employer will be violative of Section 8(a)(1) of the Act unless the following safeguards are observed: (1) the purpose of the poll is to determine the truth of a union's claim of majority, (2) this purpose is cominunicated to the employees, (3) assurances against reprisal are given, (4) the employees are polled by secret ballot, and (5) the employer has not engaged in unfair Id. labor practices or otherwise created a coercive atmosphere.

87. Montgonery Ward \& Co., 210 N.L.R.B. 717, 723 (1974).

88. In Bellwood the court characterized the employer's position:

To hold that the Hospital had no basis on which to justify a good faith doubt in the present case would place the Hospital and other employers in an extremely difficult position. On one hand, the evidence might not be held to amonnt to adequate support for a good faith doubt; on the other hand, it night be an unfair labor practice for the eniployer to bargain with a minority union in light of the cumulative evidence. . . and yet it might also be an unfair labor practice for the enployer to interview the employees regarding their preferences.

Bellwood Gen. Hosp., Inc. v. NLRB, 627 F.2d 98, 104 (7th Cir. 1980).

89. See notes $40-47$ supra and accompanying text.

90. See notes 38-57 supra and acconpanying text. 
value it may have in showing loss of majority support.91 The Board has taken a similar approach with other kinds of evidence, including evidence of poor strike support, ${ }^{92}$ proof that an einployee decertification petition has been filed (although this evidence usually receives some consideration), ${ }^{93}$ and evidence of a close certification election. ${ }^{94}$ This approach effectively precludes the employer froin showing loss of inajority support, yet the Board continues to demand that the einployer shoulder this burden. ${ }^{95}$

91. Examples include the presumption that new employees support the union in the same ratio as the workers they replace, see note 50 supra and accompanying text, and the presunuption that umion membership is not equivalent to union support, see note 54 supra and accompanying text.

92. Asserting that employees nay support a union but not support a particular strike called by that union, the Board has held that strike support is not a reliable indicator of union support and is therefore entitled to little weight. The Board has noted that an employee may refuse to support a strike because lie is unable to afford the monetary loss, afraid of losing his job, or conscientiously opposed to a particular strike. In each of these situations the employee nay still desire umion representation. Sce West Sand \& Gravel Co., 239 N.L.R.B. 931, 937, enforcement denied, 612 F.2d 1326 (1st Cir. 1979); Servomation, Inc., 235 N.L.R.B. 975, 978 (1978) (lack of strike support is not a sufficient "objective consideration" to support good-faith doubt). Some courts have been more receptive than the Board to considering evidence of poor strike support. E.g. , NLRB v. Riclard W. Kaase Co., 346 F.2d 24, 31 (6th Cir. 1965). Contra, Rogers Mfg. Co. v. NLRB, 486 F.2d 644 (6th Cir. 1973), cert. denied, 416 U.S. 937 (1974).

93. The Board's approach in this area has not been consistent. In Telautograph Corp., 199 N.L.R.B. 892 (1972), the Board held that once a valid einployee decertification petition had been filed, raising a question concerning representation, the employer could not bargain further with the union. Id. at 893. The Board changed its position in Lammert Indus., Inc., 229 N.L.R.B. 895 (1977), enforced, 578 F.2d 1223 (7th Cir. 1978), holding that the filing of an employee decertification pctition was only oue circumstance to be considered in the good-faith-doubt analysis. Although one court has adopted the Telautograph approach, see National Cash Register Co. v. NLRB, 494 F.2d 189 (8th Cir. 1974), nost courts have endorsed the Lammert approach. See, e.g., NLRB v. Maywood Plant of Grede Plastics, 628 F.2d 1, 4-5 (D.C. Cir. 1980); Retired Persons Pharmacy v. NLRB, 519 F.2d 486, 490-91 (2d Cir. 1975); Rogers Mfg. Co. v. NLRB, 486 F.2d 644, 647 (6th Cir. 1973), cert. denied, 416 U.S. 937 (1974). Although under Lammert the Board considers the decertification petition, the petition rarely is determinative since it need be supported by only $30 \%$ of the unit employees, rather than by a inajority.

94. The Board generally finds that evidence of a close certification election does not tend to prove good-faith doubt. See, e.g., Laystrom Mfg. Co., 151 N.L.R.B. 1482, 1484 (1965), enforcement denied, 359 F.2d 799 (7th Cir. 1966). But see Convair Div. of Gen. Dynamics Corp., 169 N.L.R.B. 131, 133 (1968) (that the union had won the election by only 22 votes in a unit consisting of approximately 630 cmployees is probative of good-faith donbt). Some courts have considered this kind of evidence. See NLRB v. Alvin J. Bart \& Co., 598 F.2d 1267, 1271 (2d Cir. 1979) (a close certification election renders the presunption of majority support weak at best); NLRB $\mathrm{v}$. Laystroin Mfg. Co., 359 F.2d 799, 800 (7th Cir. 1966) (the election resulted in 17 votes for the union, 13 against, and 2 ballots challenged); Capitol Aviation, Inc. v. NLRB, 355 F.2d 875 (7th Cir. 1966) (a close certification election, 29 to 26, low strike support, and normal turnover established good-faith doubt).

95. The Board has apphed the presumption of majority support in two situations in which, because of a rapid change in circumstances, the presuniption arguably ought not to apply: when a successor employer takes over the business enterprise, and when an employer withdraws from a innlti-employer bargaining unit. See Tahoe Nugget, Inc., 227 N.L.R.B. 357 (1976) (withdrawal 
An incumbent umion is in a much bettcr position than an einployer to prove majority support. In contrast to the employer's position, the union can freely question employees about their union sentiment. ${ }^{96}$ Such questioning is not regarded as coercive of employee free choice because the union's relationship with employees is different from the employer's. ${ }^{97}$ Because an employer controls the employee's livelihood, he usually has considerable power over his einployees. The implicit threat of discharge is always present. Although the union may have some control over the einployees, it cannot fire them, at least directly. Umion questioning of employees therefore is not as oppressive as employer questioning. Furthermore, a union's awareness of the extent of employee support is important in determining the union's bargaining leverage im negotiations with the employer. Most unions, therefore, probably are keenly aware of the extent of their support. Indeed, the union benefits from keeping any loss of employee support confidential; an employer cannot gain bargaining leverage if he does not know when the union loses majority support. The union also has access to its own files, which may aid it in determining the extent of employee support. On balance, the union is in a much better position than the employer to bear the burden of proof on the issue of majority status. The importance of correctly determining the majority-status issue should lead the

from multi-employer bargaining unit), enforced, 584 F.2d 293 (9th Cir. 1978), cert. denied, 442 U.S. 921 (1979); Ranch-Way, Inc., 183 N.L.R.B. 1168 (1970) (successor employer), enforced, 445 F.2d 625 (10th Cir. 1971).

The courts have supported the Board's application of the presumption in the successor-employer context. See NLRB v. Middleboro Fire Apparatus, Inc., 590 F.2d 4 (1st Cir. 1978); NLRB v. Downtown Bakery Corp., 330 F.2d 921 (6th Cir. 1964). But see Western Distrib. Co. v. NLRB, 608 F.2d 397 (10th Cir. 1979) (refusing to apply the "ancillary-ratio presuniption" to bind a successor employer). See generally Note, The Successor Employer's Obligation to Bargain: Current Problems in the Presumption of a Union's Majority Status, 8 FordHAM URB. L.J. (1980); sce also NLRB v. Burns Int'l Security Servs., Inc., 406 U.S. 272 (1972).

Some courts have supported the Board's application of the presumption of majority support when the employer withdraws from a multi-employer unit in which an election was never held. See NLRB v. Tahoe Nugget, Inc., 584 F.2d 293, 303 (9th Cir. 1978) (the presumption arises froin employer's voluntary recognition of the union), cert. denied, 442 U.S. 921 (1979). Other courts have refused to apply the presunstion with full force when it has never been shown that the single-plant unit supports the union. See, e.g., W \& W Steel Co. v. NLRB, 599 F.2d 934, 939 (10th Cir. 1979) (the ballots of seven plants were commingled in the original inulti-plant election); NLRB v. Richard W. Kaase Co., 346 F.2d 24, 31 (6th Cir. 1965) (multi-employer election too ambiguous to support a presumption of majority support in any single unit). Criticism of the Board in this context also has come from within. See 227 N.L.R.B. at 359 (Walther, Meunber, dissenting) (presumptions should not be enployed when they fail to mirror reahty).

96. R. GORMAN, supra note 30, at 176 ("In contrast to the many decisions outlawing systematic interrogation by employers, it is clear that there is no such rule barring coinparable imterrogation by unions and that unions are free to poll employees to gauge the extent of their support").

97. Springfield Discount, Inc., 195 N.L.R.B. 921 , $921-22$ n.4, enforced, 82 L.R.R.M. 2173 (7th Cir. Nov. 30, 1972). 


\section{Board to require the union to bear the burden of proof. ${ }^{98}$}

The Board's current approach also infringes on employee free choice when a group of employees has filed a decertification petition. ${ }^{99}$ Such petitions are held in abeyance if certam unfair labor practice charges, including refusal-to-bargaim charges, have been filed against the einployer. ${ }^{100}$ These unfair labor practice charges are known as "blocking charges" because they temporarily block any attempt to hold an election. ${ }^{101}$ An election is not held until the unfair labor practice charge is resolved. When an einployee election petition is filed and the employer discontinues bargaining, an incumbent union, unsure of its majority status, probably will file a refusal-to-bargain charge to block the election. In so doing the union hides its possible loss of majority status behind the einployer's burden of proof, rather than risking an unfavorable election result. Under current Board standards the employer is often unable to satisfy this burden in the unfair labor practice proceeding even when the union has lost majority support. In such a case a bargaining order issues and the employee petition is not processed further. The umion succeeds in maintaining its representative status although it no longer coininands inajority support. The employees are saddled with a representative they no longer desire. ${ }^{102}$ If the Board places the burden of proof on the union, however, unions would have little to gain by avoiding an election. A union's loss of inajority support probably would be exposed in either an election or an unfair labor practice proceeding.

98. In Peoples Gas Sys., Inc. v. NLRB, 629 F.2d 35 (D.C. Cir. 1980), the court stated that the Board's current approach "run[s] a substantial risk of frustrating actual employee wishes simply because the Board is not satisficd with the Company's ability to identify and articulate the reasons for its doubt about the Union's support." Id. at 44.

99. See notes 66-68 supra and acconipanying text.

100. See J. Feerick, H. Baer \& J. ARFA, supra note 68, at 233-36.

101. In Hod Carriers Local 840 (Blinne Constr. Co.), 135 N.L.R.B. 1153 (1962), the Board explained the underlying basis for the "blocking-charge doctrine":

A representation petition assumes an unresolved question concerning representation. A Section 8(a)(5) charge, on the other hand, presupposes that no such question exists and that the employer is wrongfully refusing to recognize or bargain with a statutory bargaining representative. Because of this basic inconsistency, the Board has over the years uniformly refused to entertain representation petitious where a meritorious charge of refusal to bargain has been filed and, indced, has dismissed any repesentation petition which inay already have been on file.

Id. at $1166 \mathrm{n} .24$.

102. See Tcmpleton v. Dixie Color Printing Co., 444 F.2d 1064 (5th Cir. 1971) (characterizing the blocking-charge doctrine as arbitrary in a case in which the cinployees' decertification petition had been held in abeyance for over three years, and upholding the jurisdiction of the district court to order the Board to process the petition); NLRB v. Minute Maid Corp., 283 F.2d 705 (5th Cir. 1960) (the Board is not relieved of its statutory duty to process a decertification petition merely because an unproved unfair labor practice charge is filed against the einployer). 
Requiring einployers to prove that an incumbent umion has lost its 1najority support simply cannot be justified on the basis of proinoting einployee free choice. Einployee free choice is better preserved by placing the burden of proving majority status on the umion. To justify its current approach, the Board must rely on the policy of industrial stability.

\section{B. Industrial Stability.}

Maintaining the continuity of collective bargaining relationships continues to be the primary means of promoting industrial stability. Arguably, an approach making it difficult to unseat an incuinbent umion, even if the union no longcr enjoys majority support, is justified because of the need for continuity. There is, after all, nothing sacred about the principle of majority rule. For example, if only forty-nine out of one hundred einployees presently support an incumbent union, the policy of industrial stability, as achieved through continuity in bargaining relationships, might best be served if the employee group is required to maintain the union as its representative. This argument seems inherent in the current Board approach. ${ }^{103}$ At some poimt, however, the policy of promoting industrial stability is no longer served by compelling recognition of a minority union. If only ten out of one hundred employees support a union, for example, a bargaining order would produce confusion and instability. The union would have very little bargaining leverage in its dealings with the employer. An einployer aware of such low union support would make few concessions to the union at the bargaining table. Moreover, the union would have so little control over the employees that it probably would not issue a strike call, but instead would settle for whatever concessions it could obtain froin the employer. With such an ineffective bargaining representative, the employer-einployee relationship would exist as if the union did not represent the employees at all. In this situation, maintaining continuity does little to promote industrial stability. ${ }^{104}$

103. Although the Board relies on both industrial stability and employee free choice to support its approach, see note 35 supra, the Board's approacl actually hinders free choice. See text accoinpanying notes 78-95 supra. The approach must, therefore, ultimately find support in the goal of promoting industrial stability.

104. Cf. Note, supra note 33 , at $659-60$. In discussing the presumption of majority support, the note's author argues:

Concededly, the presumption is likely to preserve the status quo; however, the inference that preservation of the status quo is conducive to the industrial stability envisioned by the NLRA is far from compelling. Typically the umion has been inactive for months or years prior to an employer's refusal to bargain [citing Tahoe Nugget and other cases] While this type of bargaining relationship inay create the appearance of industrial stability inasunucli as it is unlikely to give rise to strikes or other economic warfare, the intent 
The point at which the goal of industrial stability is not served by requiring an employer to bargain with a minority union varies, and it is impossible to predict the effect of a bargaining order at the time it is issued. If industrial stability were the only relevant policy, the Board perhaps should be given discretion to decide when to issue a bargaining order, and placing the burden of proof on the employer would be an appropriate exercise of administrative discretion. Industrial stability is not the ouly relevant pohicy, however, and it must always be weighed against employee free choice.

\section{The Balance Between Free Choice and Stability.}

The Act states clearly that the goal of industrial stability inust be balanced against the employees' right to choose their bargaining representative. ${ }^{105}$ Both employee free choice and industrial stability are safeguarded by sections $8(a)(2)^{106}$ and $8(a)(5)^{107}$ of the Act. The Supreme Court has interpreted section $8(a)(2)$ as generally prohibiting employer recognition of a minority union. ${ }^{108}$ Section $8(a)(5)$ compels recognition of a majority union. In theory the two sections are harmomous, but an employer often cannot know whether he is dealing with a minority or a majority union. In such situations the employer must decide whether to continue bargaining, risking a violation of one of the two sections if his decision is imcorrect. The Board's task is to guide the employer im the direction most closely satisfying the policies underlying the Act. ${ }^{109}$ The Board has ignored section 8(a)(2) in the incunibency situation, however, by compelling the employer to resolve all doubts in

\footnotetext{
of the statute is to protect.only that industrial stability resnlting from actual collective bargaining with the employees' chosen representative. Thus, to the extent the Board's presumption preserves bargaining relationships other than those envisioned by the statId. ute, it cannot legitimately be based upon preservation of the status quo.

105. See notes 3-4 supra and accompanying text.

106. Section 8(a)(2) of the Act makes it an unfair labor practice for an employer "to dominate or interfere with the formation or administration of any labor organization or contribute financial or other support to it . . ." 29 U.S.C. \& 158(a)(2) (1976).

107. 29 U.S.C. \& 158(a)(5) (1976). See note 10 supra.

108. ILGWU v. NLRB (Bernhard-Altinan Tex. Corp.), 366 U.S. 731 (1961). Although Bernhard-Altman is an initial-recognition case, the rule barring recognition of minority unions has been applied in the incunibency situation. See Kenrich Petrochemicals, Inc., 149 N.L.R.B. 910 (1964). The exceptions to this general rule, most notably the "contract-bar" and "certificationyear" doctrines, are discussed at notes 115-21 infra and accompanying text.

109. Sce notes 1-5 supra and accompanying text. Because section 8(a)(5), 29 U.S.C. \& 158(a)(5) (1976), im practice requires the employer to maintain the bargaining relationship if he has only some doubt of the union's majority status, the section promotes industrial stability. Section 8(a)(2), 29 U.S.C. \& 158(a)(2) (1976), should lave the opposite effect, forcing the employer to resolve doubts against recognition. If the employer guesses correctly about the union's status when le refuses to bargain, employee free cloice is enhanced.
} 
favor of recognition in order to avoid an 8(a)(5) violation. ${ }^{110}$ In addition, by placing the burden of disproving majority status on the employer in $8(\mathrm{a})(5)$ cases, the Board has rendered section $8(\mathrm{a})(2)$ ineffective in the incumbency context.111

The Board's discretion im fashioning remedies 112 and determining substantive law is limited when the policies of the Act are relatively clear. ${ }^{113}$ In enacting the Act, Congress weighed einployee free choice against industrial stability and determined that the goal of employee free choice outweighs the goal of industrial stability when a union no longer commands majority support. ${ }^{114}$ The Board should not independently weigh these two policies and apply a rule that is inconsistent with the policy balance mandated by Congress.

The Board lias contravened this mandate, however, by favoring industrial stability over employee free choice. To administer Congress's espoused policy faithfully, the Board should apply a standard that ensures an accurate determination of actual majority status. $\mathrm{Re}$ quiring the umion to bear the burden of proving majority status accomplishes this goal.

The contract-bar doctrine and the certification-year rule, which each limit employee free choice while promotimg industrial stability, are distimguishable from the Board's placing of the burden of proof on the employer in the mcumbent-union context. The contract-bar doctrine protects the union from an attack on its majority status by the employer or the employees during the period of the collective bargaining agreement, for a maximum of three years. ${ }^{115}$ The certification-year rule similarly protects the umion during its initial year of recognition,

110. This conclusion is supported by the dearth of reported decisions involving section 8(a)(2) violations in the incumbency situation.

111. Another cause of the elnasculation of this section in the incumbency context is the Board's "knowledge requirement." The Board will not find the employer guilty of violating section 8(a)(2), 29 U.S.C. \& 158(a)(2) (1976), unless the employer has knowledge that the incumbent union no longer commands majority support. See Campus Housekeeping, Inc., 252 N.L.R.B. No. 72, 105 L.R.R.M. 1527 (Sept. 29, 1980); Clark Equip. Co., 249 N.L.R.B. 660 (1980); Kenrich Petrochemicals, Inc., 149 N.L.R.B. 910, 911 (1964) ("We rest our finding [of an 8(a)(2) violation] . . . solely on the fact that . . . the Company . . . knew that the Union did not represent a majority of the employees in the appropriate unit") (enphasis in original).

112. See Fibreboard Paper Prods. Corp. v. NLRB, 379 U.S. 203, 217 (1964).

113. A Board order will not be enforced if "the order is a patent attempt to achieve ends other than those which can fairly be said to effectuate the policies of the Act." Virginia Elec. \& Power Co. v. NLRB, 319 U.S. 533, 540 (1943).

114. The clearest statement of this congressional intent is found in section $9($ a), 29 U.S.C. $\S 159$ (a) (1976), see notes 4,9 supra, which provides that only representatives selected by a majority of employees are entitled to exclusive recognition by the employer.

115. For a discussion of the contract-bar rule, see A. Cox, D. BOK \& R. GORMAN, supra note 78 , at $285-94$. 
regardless of whether it has entered into a collective bargaining agreement with the employer. ${ }^{116}$ Both doctrines are at least partially designed to mamtain industrial stability. By insulating the union against attack for specified time periods, the Board gives it a chance to prove itself worthy of its designation as representative of the bargaining unit. After these periods the einployees' evaluation of a union's perforinance should be determinative. With regard to both doctrines, the Board has had to weigh policies other than the promotion of employee free choice and industrial stability. The contract-bar rule is in part the product of the policy favoring the perfornance of contractual obligations. ${ }^{117}$ Without such a rule, collective bargaining agreements would have little meaning. ${ }^{118}$ When a collective bargaining contract is entered into, the union has the majority support of the employees and the agreeinent therefore is binding on the einployee unit. The einployee unit should not be allowed immediately to escape its contractual obligations merely because it has changed its inind about its bargaining representative.

Similarly, the certification-year rule is not based exclusively on promoting the goal of industrial stability. The rule also ensures that employees do not take elections for granted, but treat thein as solemn and serious occasions. ${ }^{119}$ The rule promotes a sense of responsibility in the employee electorate by providing for a minimun fixed tern of union representation, except under the most unusual circumstances. ${ }^{120}$

In applying both the contract-bar and certification-year rules the Board has not substituted its own policy views for Congress's. Rather, the Board has created specialized factual exceptions to the majority -rule principle based on policies that Congress failed to consider. In contrast, by placing the burden of proving that the mcunibent union lacks majority support on the eniployer, the Board has directly contravened Congress's policy determination that recognition of a ininority union is improper under the Act. This issue presents no relevant policies otlier than employee free choice and industrial stability, and eacl1 of these policies has been considered by Congress and provided for in the Act. ${ }^{121}$

116. See notes 14-15 supra and accompanying text.

117. See A. Cox, D. BoK \& R. GoRMAN, supra note 78, at 285-94.

118. Id.

119. Brooks v. NLRB, 348 U.S. 96,99 (1954).

120. Id.

121. Another situation in which the Board will issue a bargaining order even though the union no longer commands majority support is when an employer has undermined the union's support through his own unfair labor practices. This situation is easily distinguished from the normal incumbency situation, and a bargaining order is necessary here if the employer is not to profit by 


\section{ConClusion}

An employer should not be allowed to challenge a union's status arbitrarily. Employers must be required to satisfy some evidentiary burden to prevent harassment of the union by employer challenges to the union's majority status. 122 Application of the good-faith-doubt test as used by the Board in Stoner and the court in Bellwood is warranted. ${ }^{123}$ If the employer cannot meet this minimal standard, the Board is justified in entering a bargaining order. If, however, the employer's doubts are both reasonable and in good faith, the Board should find that the presumption of majority support has been rebutted, and should enter a bargaining order only if the union persuades the Board that its majority status still exists. This standard of proof strikes the proper balance, as determined by Congress, between the goal of employee free choice and the goal of industrial stability.

The suggested approach probably will result in higher union turnover. Only those unions that truly coininand majority support will be allowed to represent employees. Unsupported, albeit entrenched, unions no longer will burden employee units simply because the unions previously commanded majority support. The suggested approach may even lead to less unionization. But under the Act the question of unionization always has been left to those niost significantly affected by that determination: the employees. The Board has lost sight of this consideration, forcing its preference for industrial stability upon employee units, rather than deferring to the employees and fulfilling its congressionally-prescribed role.

Joel B. Toomey

his own wrongdoing. As far as the Board is concerned, when the effects of the employer's unfair labor practices undermine employee support of the union, the union should be deemed still to command majority support. See Franks Bros. v. NLRB, 321 U.S. 702 (1944).

122. See note 74 supra.

123. See text accompanying notes 25,63 supra. 